History and Chemistry of Drugs". Prof. Edman's investigations have dealt with several aspects of drugs of vegetable origin. These include studies of the ash content and the presence of silica in drugs and the application of chemomicroscopical tests. His numerous microscopical studies of structure have been directed towards the discovery of adulteration, and to the identification and standardization by structural characters of crude vegetable drugs both in the unground condition and in the form of powder. The Medal will be presented at a meeting of the Society on February 9, when Prof. Edman will give an address entitled "Ash Pictures in the Identification and Assay of Vegetable Drugs".

\section{American Academy of Arts and Sciences: Rumford Medals}

Rumford Medals of the American Academy of Arts and Sciences have been awarded to the following : Prof. Enrico Fermi, of the University of Chicago, for his studies of radiation theory and nuclear energy Prof. Willis Eugene Lamb, jun., of Stanford University, for his studies of the atomic hydrogen spectrum; and Prof. Lars Onsager, of Yale University, for his contribution to the thermodynamics of irreversible flow. The bicentenary of the birth of Benjamin Thompson, Count Rumford, will be celebrated by the Academy in Boston during March 26-28, 1953, when the Medals will be presented and conferences arranged on the fields of science represented by the recipients. Rumford was born at Woburn, Mass., now a suburb of Boston, on March 26, 1753, and in 1796 he gave a fund to the Academy to be used for the awarding of gold and silver medals to encourage scientific investigations in the field of heat and light. To date forty-eight Rumford Medals have been awarded.

\section{American Section of the Society of Chemical Industry: Perkin Medal}

THE American Section of the Society of Chemical Industry has awarded the Perkin Medal for 1953 to Dr. Charles Allen Thomas, president of Monsanto Chemical Co., St. Louis, and chairman of the board of directors of the American Chemical Society. The Perkin Medal, of which this is the forty-seventh award, is given for outstanding achievements in applied chemistry and was founded in 1906, being first awarded to Sir William Henry Perkin in commemoration of the fiftieth anniversary of his synthesis of mauve, the first synthetic dye. Dr. Thomas has made outstanding contributions to many phases of industrial chemical development-including the atomic energy programme; several phases of the pioneer development and general utilization of anti-knock, high compression fuels for internal combustion engines; important contributions to knowledge of the chemical reactions of hydrocarbons in the presence of catalysts, particularly aluminium chloride; synthesis of resins and other useful products from petroleum and its by-products; and fire-fighting devices and methods-as well as for his leadership in both the profession and industry of chemistry.

Sheep Biology Laboratory, Prospect, New South Wales

A NEw Sheep Biology Laboratory has recently been set up at Prospect, near Parramatta, New South Wales, by the Commonwealth Scientific and Industrial Research Organization, and Prof. C. W. Emmens has been appointed as officer-in-charge. Prof.
Emmens has a distinguished record as an animal physiologist and was for many years engaged on research at the National Institute for Medical Research, London; concurrent with his new post, he will continue his present work as professor of veterinary physiology in the University of Sydney. The Prospect Laboratory will concentrate on problems of fertility and reproduction, the physiology of wool production, and sheep breeding and genetics, and it is hoped eventually to build it up as a leading world centre of information on all scientific data relating to sheep and wool husbandry, particularly the Merino and other types specially evolved in Australia. A balanced programme of both laboratory studies and field investigation is planned to develop the potentialities of healthy sheep in terms of quality and quantity of fleece, higher lambing percentages and the breeding cf specialized types. Linked with the central Laboratory will be a series of sheep and wool field-stations in the major wool-producing regions, equipped to study all relevant aspects of soils, pastures, animal husbandry, disease control and plant and animal management. The Laboratory is being established on an area of 130 acres which has been carefully selected to provide good potential for pasture management and improvement and space for the cultivation of fodder crops. The full building programme will not be complete for some time, but sufficient laboratory accommodation and animal houses, feed stores, fleece and shearing sheds are now available in prefabricated buildings to enable research to be started.

\section{Abstracting Board of the International Council of Scientific Unions}

THE International Council of Scientific Unions has set up an Abstracting Board (Bureau des Résumés Analytiques du C.I.U.S.) with the purpose of facilitating the work of existing well-established journals publishing abstracts of original papers in the field of the natural sciences (see p. 960). A beginning has been made in the field of physics, and two member journals, Physics Abstracts and the Bulletin Analytique, are represented on the Board. In principle, any journal can seek membership to the Board, which is constituted, under a neutral chairman, of representatives of the interested International Unions and representatives of the member journals, together with the secretary-general of the Council as an exofficio member. The present constitution of the Board is as follows : Chairman, Dr. Verner W. Clapp (assistant librarian, Library of Congress) ; Secretary, Prof. G. A. Boutry (Paris); Members, Dean Elmer Hutchisson (Case Institute of Technology), representing the International Union of Pure and Applied Physics, Dr. J. H. Ashery, representing Science Abstracts, Dr. G. Kersaint, representing Bulletin Analytique, Prof. A. V. Hill (secretary-general of the International Council of Scientific Unions). Dr. L. H. Lampitt sits as an observer for the International Union of Pure and Applied Chemistry. The offices of the secretariat are at the Institut d'Optique, 3 Boulevard Pasteur, Paris 15e, where work has already begun with the aid of a special subvention from Unesco. The secretary of the Board will gladly give any information desired about the facilities which can be extended to member journals.

\section{Preservation of the Peak District}

THE annual report for the year up to May 1952 of the Sheffield and Peak District Branch of the Council for the Preservation of Rural England (pp. 